\title{
Representations of Peronism as totalitarianism in the view of the Socialist Party during a Cold War period in Argentina (1950-1955)
}

\author{
Juan Pablo Artinian \\ Universidad de Buenos Aires, Zip Code 1406, 1435 Hortiguera street, Buenos Aires \\ e-mail:artinianjuanpablo@gmail.com
}

Submitted: 7 May 2014. Accepted: 27 November 2014

\begin{abstract}
This article analyzes forms of cultural production that opposed Peronism in Argentina between 1950 and 1955 in the context of the Cold War. It focuses on representations created by Argentina's Socialist Party. This party created a series of discourses opposed to Peronism using local and transnational categories that were framed by the country's own view of the Cold War. The Socialist Party used these discourses to stigmatize Perón's Argentina as a species of totalitarian state. This article sought to go beyond the traditional perspectives of Cold War historiography, whose focus is on diplomatic and military history and the bulk of whose analysis is devoted to dissecting the United States' attempts to establish hegemony over Latin America or to describing the phenomenon of justicialismo's "third position." This article, on the other hand, sought to use cultural analysis to explore Latin America's own agency in its adoption of language pertaining to the early Cold War period. Socialists crafted a stylized, and sometimes exaggerated, discourse in which imagery belonging to fascism and, to a lesser extent, Stalinism after the rise of the Iron Curtain, was combined with the local figure of nineteenth century governor Juan Manuel de Rosas.
\end{abstract}

KEYWORDS: Latin America; cultural production; Peron Evita; Fascism; totalitarianism

Citation / Cómo citar este artículo: Artinian, Juan Pablo (2015). "Representations of Peronism as totalitarianism in the view of the Socialist Party during a Cold War period in Argentina (1950-1955)". Culture \& History Digital Journal, 4 (1): e005. doi: http://dx.doi.org/10.3989/chdj.2015.005

RESUMEN: Representaciones del peronismo como totalitarismo en la mirada del Partido Socialista durante la temprana Guerra Fría en Argentina (1950-1955).- Este artículo analiza formas culturales que se opusieron al Peronismo en Argentina entre 1950 y 1955 en el contexto de la Guerra Fría. El artículo se focaliza en las representaciones creadas por el Partido Socialista Argentino. Este partido creó una serie de discursos opuestos al peronismo a través de categorías e ideas trasnacionales y locales enmarcadas en nociones propias de la Guerra Fría. Así el Partido Socialista estigmatizó al peronismo como una forma de estado totalitario. Este artículo busca ir más allá de las visiones tradicionales de la historiografía sobre la Guerra Fría basadas en la historia diplomática o militar donde gran parte del análisis daba cuenta de los intentos hegemónicos de los Estados Unidos en la región o mostrar el fenómeno de la denominada "tercera posición" justicialista. Este trabajo por el contrario busca explorar desde una análisis de la historia cultural la agencia propia de América Latina en sus usos del lenguaje de la Guerra Fría. Así los socialistas elaboraron un estilizado y por momentos exagerado discurso donde tanto imágenes propias del fascismo y en menor medida del estalinismo posterior a la Cortina de Hierro se mezclaban con la figura del gobernador del siglo XIX Juan Manuel de Rosas.

PALABRAS CLAVE: América Latina; producción cultural; Perón Evita; Fascismo; Totalitarismo

Copyright: $(1) 2015$ CSIC This is an open-access article distributed under the terms of the Creative Commons AttributionNon Commercial (by-nc) Spain 3.0 License. 
On August 22nd, 1951 in Buenos Aires, a crowd of more than a million took part in Justicialismo's Open Cabildo. The crowd took up a large section of the 9 de Julio, Buenos Aires's main thoroughfare, while a stage was set up in front of the Bienestar Social building, where thousands of demonstrators demanded that Evita be made Juan Perón's vice-presidential candidate in the upcoming election of 1952. After the crowd had waited for over eight hours, and as night was coming on, Evita announced to all those assembled her "historic renunciation" to office the vice-presidency (Navarro, 2011: 282-284). The event that came to be known as Justicialismo's Open Cabildo was criticized by one of Peronism's leading opponents: the Socialist Party. Nuevas Bases, the primary organ for the diffusion of socialist opinion, referred this to this enormous Peronist gathering as the "triumph of the totalitarian state."

This article will analyze forms of cultural production that opposed Peronism in Argentina between 1950 and 1955 in the context of the Cold War. It will focus on representations created by Argentina's Socialist Party. This party created a series of discourses opposed to Peronism using local and transnational categories that were framed by the country's own view of the Cold War. The Socialist Party used these discourses to stigmatize Perón's Argentina as a species of totalitarian state. ${ }^{1}$ At the same time, socialists depicted the idea of totalitarianism using a form of discourse specific to Argentina that had its roots in the country's liberal tradition, comparing Perón to the figure that, in this tradition, embodied authoritarianism in the nineteenth century: Juan Manuel de Rosas.

\section{LATIN AMERICAN PERSPECTIVES ON THE COLD WAR}

In general, the historiography of the Cold War period in Latin America has revolved around the idea of a bipolar conflict and examined the ways that the superpowers wielded their power and influence in the "third world." This has been particularly true of Argentine historiography. At the same time, a traditional emphasis on the region's diplomatic and political history has led historians to focus their research on the United States' attempts to establish hegemonic rule over Latin America (Calandra and Franco, 2012). Argentina's own tensions with the United States have been studied extensively by local historiography. Still, over the past few years, a number of analyses have called this academic orientation into question. Historians have begun to scrutinize local dynamics, Latin America's own agency, and the roles that social and political actors other than the state played during the Cold War. Meanwhile, new perspectives that take into account issues raised by social and cultural historians have begun to emerge and take their place alongside traditionally minded analyses that focus on political, diplomatic, or military history (Harmer, 2011 and Morgenfeld, 2011). This article aligns itself with these new viewpoints and will try to develop a narrative in which local Argentine political dynamics, defined by political and cultural rivalries that existed during the Peronist period, generated a set of political discourses linked to Argentines' own ideas about the Cold War. It will seek to go beyond works that have focused on the influence and pressure exerted on Argentina by the United States or analyses that have argued that Argentina assumed a "third position" during the Peronist period. If our analysis deemphasizes these historical tensions, we affirm that our examination of socialists' criticisms of Peronism will contribute to a narrative that shows that the symbolic production that dealt with Cold War issues in Argentina was not just a local discourse, but also a transnational one.

This article will employ some analytical strategies that are associated with the study of cultural history. I will analyze the cultural production of Argentina's socialists following Lynn Hunt's concept of political culture (Hunt, 1984:10-11). At the same time, we will utilize methodologies originated by Peter Burke to analyze visual source material (Burke, 2001). Burke posits that visual sources should be read independently from the artist's intention and should be considered historical documents in the same way that oral and written sources are. ${ }^{2}$

Until now, few academic studies have examined the cultural production of the Socialist Party. ${ }^{3}$ Even fewer have attempted to analyze the visual universe created by this party during Peronism's "classic" period. We should, then, ask ourselves the following questions: What means of production did this party employ to create a political culture of their own? How did they speak to their common political base - the working class - as they competed with Peronism for adherents? Most importantly, how did the language typical of the Cold War manifest itself in the political culture produced by the socialists who sought to challenge Peronism?

\section{ATTEMPTS TO CREATE A PERONIST CULTURAL HEGEMONY}

In 1943 - a group of army officers, one of whom was Juan Domingo Perón - took power. Perón took charge of the old Departamento de Trabajo y Prevision - the department of labor and planning - which he made into a Secretariat. He also served as Argentina's minister of war and as its vice-president. During the period that he led the Secretaría de Trabajo y Previsión, Perón established strong ties to the country's labor unions. Perón, then a rising star in Argentina's government, was watched jealously by the officers who had appointed him to his post and later imprisoned on the island of Martín García. Argentina's workers reacted by staging a march to the Plaza de Mayo on October $17^{\text {th }}, 1945$. After freeing Perón, the country's de facto government scheduled elections. The United States took an active role during the presidential campaign, denouncing Perón and criticizing him as a local follower of the fascist movement, which had recently been crushed in Europe. These circumstances gave the discourse formulated by the so-called Unión Democráti- 
ca, a disparate group which included the Unión Cívica Radical, the Partido Socialista, the Partido Comunista, and the Partido Demócrata Progresista, a transnational dimension. This discourse called on Argentines to fight what they termed "nazifascismo" and to embrace a liberal ideology.

Between 1946 and 1955, Peronism shifted Argentina's political, social, and cultural coordinates. ${ }^{4}$ The government purchased the railroads, which had been in British hands, nationalized power and water companies, and took control of the country's foreign trade. Ramping up trends that first appeared in the aftermath of the First World War, it sought to protect Argentina's growing domestic market. Peronism offered, as Eduardo Elena has pointed out, novel policies meant to increase the buying power of Argentine workers. This rise in the so-called quality of life was one of the justicialist government's main objectives (Elena, 2011). At the same time, Juan Perón continued the social policy that he had maintained as minister for labor and planning. This reinforced his relationship with the unions and expanded the "social rights" of sectors of the population that had previously been neglected, such as children, the elderly, and the poor. The Fundación Eva Perón also took a central role in implementing the government's social policies (Navarro, 2011: 235-262)

The first years of the nineteen fifties marked the high point of Peronism's efforts to impose a cultural hegemony on the country. Publications that opposed the government were pressured in a number of ways. The newspaper La Prensa was confiscated in 1951 and made to surrender to the Confederación General del Trabajo. In addition to exerting this sort of pressure on the graphic production of opposition forces, the Peronist government used magazines, pamphlets, and posters, which it displayed in the streets of all of Argentina's cities, inside its government buildings, and even in private homes, to create an entire universe of symbols, political meanings, and images. Portraits and busts of Perón and Evita appeared throughout the country. At the same time, new Peronist rituals, most notably those performed on the first of May and on the $17^{\text {th }}$ of October, became occasions on which the connection between the leader and the workers could be reaffirmed (Plotkin, 2007).

The constitutional reform of 1949 made the cultural reform of the country one of its goals. The creation of a specifically Peronist web of symbols and political meanings became a government priority, as well as one of its signatures (Gené, 2005: 29-64). One of the key figures assigned to carry out these objectives was Raúl Apold, a man previously connected with the world of advertising, who served as the government's undersecretary for information. His office was in charge of producing posters, books, and other official publications, as well as audiovisual works designed to spread Peronism's message. The diffusion of "Peronist doctrine" took place within the Peronist movement as well, but the government sought to expand the reach of its message to civil society as a whole. A comparative analysis of Peronism and the regime of
Getulio Vargas by historian Maria Helena Rolim Capelato asserts that thanks to Peronist symbols and rituals "a mass politics was introduced which led to the formation of a new political culture" (Capelato 1994: 141). In that political culture, images of leaders, of laboring masses, and of their "enemies" shaped the representations of the antinomies that defined the conflict that swept over Argentina during this period.

\section{SECTORS OPPOSED TO PERONISM}

This analysis will examine the period beginning in 1950 owing, in part, to the increased level of pressure that the Peronist government subjected opposition parties and anti-Peronist elements from this date until 1955. After the so-called year of the Liberator (the centennial of General José de San Martin's death), both the Communist and Socialist parties endured various forms of repression that led, eventually, to the closing of the Communist Party's periodical, La Hora. After 1950, it disseminated its views through new periodical, Nuestra Palabra. Similarly, the Socialist Party's organ, La Vanguardia, helmed by Américo Ghioldi, was shuttered in 1947 and subsequently reorganized as Nuevas Bases.

Despite the enormous quantities of official propaganda produced during the early fifties, competing representations of the Perón government were also produced and circulated in Buenos Aires. The creation of a counterculture that confronted Peronism was a complex process and was the result of various related modes of political action. The most famous incidence of artists opposing the government - and one that took on a transnational dimension - involved a group that formed around Sur magazine. The key figures here included writers Jorge Luis Borges, Adolfo Bioy Casares, and Victoria Ocampo, all of whom were identified with high art. In this context other anti-Peronist groups drew the bulk of their support from the Catholic Church, university students, and a variety of political parties that appealed to the middle classes and made up a large portion of the political Left during the waning days of Peronism. It was during this turbulent period that differing modes of representation - including visual representation - became important tools for the subversion of established political and cultural values and their potential meanings. Groups of artists, who were often associated with the Socialist and Communist parties, were often in contact with writers, intellectuals, and others who critiqued Peronism's cultural and political practices.

\section{THE SOCIALIST PARTY AND ITS IMAGES OPPOSING PERONISM}

La Vanguardia, the organ of the Socialist Party, was founded in April 1894 in Buenos Aires. Two years later, various Socialist groups active in the political scene of the late nineteenth century coalesced to form the Socialist Party. This political entity sought to become Argentina's first modern political party. Its founding documents 
called for the development of laws related to labor rights and, in 1904, a young lawyer named Alfredo Palacios became Latin America's first Socialist representative. ${ }^{5}$ The party had a strong theoretical bent, was strongly influenced by positivism, and distinguished itself by maintaining an evolutionist perspective on politics and supporting gradualist, reform-minded positions. During the nineteen twenties, the Socialists participated in a number of parliamentary elections, in marked contrast to anarchist and syndicalist elements that rejected any engagement with what they considered a political system dominated by the bourgeoisie. After the so-called Concordancia period of the thirties, the Socialist Party played a part in the various attempts to create a local version of a Popular Front. Later the party was a member of Perón's opposition joining the Unión Democrática in 1945.

The Socialists offered a strong moral rebuke to the sessions of October 1945, condemning in particular their calls for worker mobilization and denying that they had taken part in their drafting. An article in the Socialists' newspaper pointed out the notable absence of workers among the demonstrators supporting Perón:

\begin{abstract}
...Those who for many years past have sustained an now sustain in their union organizations the struggles against capital; those who sustain the dignity of their functions...as citizens...were not present on that day (...) What Argentine worker acts in a demonstration demanding his rights as he would in a carnival parade...? ${ }^{6}$
\end{abstract}

This rather abstract characterization of the Argentine working class implies that it did not play any role in the $17^{\text {th }}$ of October mobilization. This stylized vision of what workers should be like and - perhaps more importantly - how they should behave, would be displayed prominently in the pages of La Vanguardia, as we will soon see.

In February 1946, Perón was elected, which meant a political disaster for the Socialist Party. Socialists could not even achieve one seat in Parliament and lost their influence in areas that had historically been theirs, such as Buenos Aires. Although UCR, inside the Unión Democrática, coalition did achieve parliamentary representation, Socialists became the most prominent dissidents that would raise their voice against Peronism. They criticized Peronism by different means, such as articles and satires published in La Vanguardia. However, Socialists deployed more than just symbolic and visual criticism. They were also involved in various attempts to overthrow Perón, such as the failed 1951 coup. Four years later, Socialists would be part of Perón's violent displacement. How can we understand Socialists' deep antipathy for Perón's political movement? Socialists saw most of the pro-worker demands they had been defending since 1895, such as higher wages, women's suffrage, and workers' political participation, in the hands of a political figure other than themselves. The very political foundation that Socialism had always pursued was now being transferred to Peronism, thus yielding the decline of Socialist party itself.

The criticisms of Peronism that appeared in Socialist Party publications took several forms. First, they characterized Peronism as a local form of totalitarianism. This charge also implied that Peronist methods were reminiscent of the authoritarian methods employed by the nineteenth century's governor of Buenos Aires, Juan Manuel de Rosas. ${ }^{7}$ Socialists' objections to Perón's policies tended to draw upon a stylized view of the working class and what they considered Peronism's natural hostility to working-class interests. Their strongest criticisms, however, were reserved for the figures of Juan Domingo and Eva Perón. The entire visual repertoire of the Socialist Party, which included biting satires and extreme characterizations of the head of state and his wife, was used to create a visual language that portrayed them as leaders of a totalitarian state.

\section{PERONISM AS TOTALITARIANISM}

In August 1947 the presses of La Vanguardia were shut down. It was followed by El Socialista, which published between 1948 and 1949, and La Lucha, which published briefly between November 1949 and March $1950{ }^{8}$ After a suit was brought against La Lucha's publishers, another mouthpiece, Nuevas Bases, began publication and operated until Peronism's fall. ${ }^{9}$ Notoriously, the newspaper's name made reference to a work by argentine liberal thinker Juan Bautista Alberdi first published in 1852, Bases y puntos de partida para la organización de la República Argentina. The new name chosen for the Socialist Party's official organ suggested that they had qualified their militant ethos and now sought an image rooted in Argentina's liberal tradition (Alberdi, 1943 [1852]).

In Socialist discourse, notions about citizenship, progress, reason and democracy directly confronted what they saw as Peronism's principal "evils": demagoguery and authoritarianism. Following the works of Argentine historian Carlos Herrera, the main thrust of the Socialists' strategy, according to their leader, Américo Ghioldi, was to characterize Peronism as a form of totalitarianism. ${ }^{10}$ In the face of this so-called totalitarianism, the Socialist Party fashioned a liberal tradition rooted in a genealogy that harked back to the independence movement of 1810. In Socialist publications, the figure of Juan Manuel de Rosas and his government were consistently and didactically portrayed as the antithesis to this democratic heritage and the progenitor of authoritarianism and anti-liberal traditions. ${ }^{11}$ The Socialists employed Rosas's personage as a tool with which to criticize Perón, whose attempt to cast himself as the "restorer of law" they considered a harbinger of authoritarianism on culture and education. ${ }^{12}$ The stigmatization of peronism as barbarism started with October $17^{\text {th }} .{ }^{13}$ Their criticisms were often accompanied by illustrations that sought to reinterpret the contemporary political landscape through the lens of traditional liberalism. An article published in 
Nuevas Bases might include an illustration depicting the execution of Camila O'Gorman, who went to the firing squad during the Rosas regime, or a picture of a murdered man titled "one savage fewer." 14 The larger idea at work was that "Rosism" was synonymous with barbarity and analogous to Peronism. Maristella Svampa also assets that "the negative symbolic power that the parallel between Rosas and Perón had would be exploited by the opposition throughout nine years of Justicialist governance" (Swampa, 2006: 329).

Beyond their comparisons to Rosas, the visual universe of Socialism was saturated with images that compared Peronism with Italian fascism and, to a lesser extent, Nazi Germany and Stalinism. In the early fifties, Socialists denounced Peronism's election campaigns as fascist ploys, decrying "the audacity of using the façades of the political headquarters belonging to opposing political parties to spread their own propaganda, a typically fascist tactic." 15 Socialists repeatedly denounced the government's supposedly totalitarian character. In speeches, their leader, Nicolás Repetto, protested constraints on the freedom of the press and drew analogies between fascism and Peronism, citing the latter's use of civic rituals and speeches given from balconies, and identifying alleged historical "similarities" between Mussolini's March on Rome and the events of October the $17^{\text {th }}$. Comparing Peronism to both the Rosas government and Nazi Germany became one of Socialist rhetoric's recurring strategies:

We must go back to Rosas to get such a gloomy picture of the state of our nation: houses marked, official uniforms regulated, the obligatory use of the federal headband, the widespread enforcement of smiles as a federal institution, attacks in the newspapers, and the hurling of shameful epithets against unclean, wild, and crazy opponents.

We must turn our eyes to Nazi Germany, which ordained the use of certain colors to signal the houses of Jews and established certain benches in plazas to be used only by Jews. The only difference is that here Argentines belong to the oppositions are the Jews in this situation. ${ }^{16}$

These discursive tactics were accompanied by a variety of illustrations. We can find one example, a sort of hybrid representation in which the figure of Rosas is adored by a genuflecting figure whose hat is adorned with a Nazi symbol. The analysis here is blunt: "This is justicialismo!" 17

Another tactic that the Socialists employed to criticize the government was the subversion of Peronist rituals and signifiers. For example, their assertion that "The $22^{\text {nd }}$ of August was a triumph for the totalitarian state," makes reference to the Peronism's "open town hall (cabildo abierto del justicialismo)" event of 1951, in which Eva Perón "renounced" her candidacy for the vice-presidency and her withdrew from the joint Juan Perón/Evita ticket while standing before a crowd that expected her to affirm her candidacy instead. Socialist critics, however, described the crowd in the following way, "a portion of the people were placed in the sad situation of imploring their prefabricated idols on behalf of the machinery of the State..."18 The meaning of this Peronist ritual became, in the Party's rhetoric, the "closed town hall of totalitarianism." The article also describes the Peronist phenomenon using a language identified with the Cold War in which terms like "totalitarianism" and "Iron Curtain" could be used to discredit Peronism: "Today, it is only in Russia and in countries behind the 'Iron Curtain' that we see carnivals like the one we witnessed in Buenos Aires". ${ }^{19}$

Socialist commentaries and representation were a part of the Cold War's tensions and rhetoric and were framed in transnational terms. Thus, we find frequent references to totalitarianism in clandestine editions of La Vanguardia as well as in articles published in Nuevas Bases. At the beginning of the 1950s, an article titled "In the Fourth Year of the Ignominy," socialists wrote that "Argentina's disease is deeply rooted, since it affects the conflict between the behavior of men as it is governed by a cruel and totalitarian statism and the introspective and moral conscience of men that mandates all possible good, truth, justice, and liberty." ${ }^{20}$ Socialist language was employed in a discourse through which local realities were incorporated into a global context. Actually some socialist in exile lecturer about the reality in Argentina framed in the categories of "freedom" versus "dictatorship." ${ }^{21}$ In another article, also from the early fifties, the Socialist Party criticized Peronism by stating that "Totalitarianism tends to legitimize lies and violence, exalting them as the ultimate principles of individual and collective life." Once again, a parallel was made with Rosas, but at the same time an allusion was made to a transnational context in which Peronism was equated with the phenomenon of totalitarianism. Thus, "In Italy and Germany, in our own century, as in Russia and Spain, the same pattern, the same system, amplified and perfected." 22 The local was linked with a global phenomenon which had, in the view of the socialists, echoes of the Cold War's own totalitarianism: the Soviet Union. Thus, as the end of Peronism approaches, socialists draw parallels between the injustices committed by Josef Stalin and by Perón. In an article published La Vanguardia, socialists claimed:

Imitating Stalin, Perón has just established a "Perón" prize, worth a million pesos, for a certain type of American work. Not being big, he likes to look puffed-up; not having received the Nobel Prize that he lobbied for so vigorously in 1947, he creates the Perón prize with state funds. Who knows if he isn't thinking of awarding it to himself, for his impending services as a great American, in the style of Rosas. ${ }^{23}$

Socialist criticisms of Peronism, which were virulently worded and clandestinely distributed, made their way through a network of socialists who engaged in politics beyond Argentina's borders. Four years after La Vanguardia was shut down, a "special tribute edition" produced by a publishing house operating in Uruguay appeared. Its 
cover, featured a clear reference to a country that, in the eyes of the Socialist Party, had been subsumed by totalitarianism: a prisoner being held in a concentration camp (see Figure 1). ${ }^{24}$

This issue also contained a reproduction of the Francisco Goya etching "La Libertad Asesinada" and a reprint of the proclamation by the Primera Junta of June $2^{\text {nd }}$, 1810, entitled "Free Press" and decorated with a Phrygian cap, which recounted the ideology of that most famous May. ${ }^{25}$ A reprint of a proclamation of Rosas's government, dated May $1^{\text {st }}, 1832$, that regulated the press ("the press in chains") provided, yet again, a clear contrast between an imagined liberal tradition and the "tyranny" embodied by Rosas. Beyond these reminders of the Rosas administration, the leitmotif of the Socialists can be summed up by a passage found in an article titled "In the Fourth Year of the Ignominy" authored by Américo Ghioldi, editor of La Vanguardia, which asked "What was the role of La Vanguardia in the Socialist Party? Asserting, demonstrating, and clarifying, to the fullest extent, that what is happening in our midst is fascism, or a totalitarian reaction." ${ }^{26}$ Socialists depicted both their own conception of totalitarianism and what they proclaimed to be its antithesis: Socialism as understood as the embodiment of resistance, a theme that was frequently referenced in Socialist publications. ${ }^{27}$

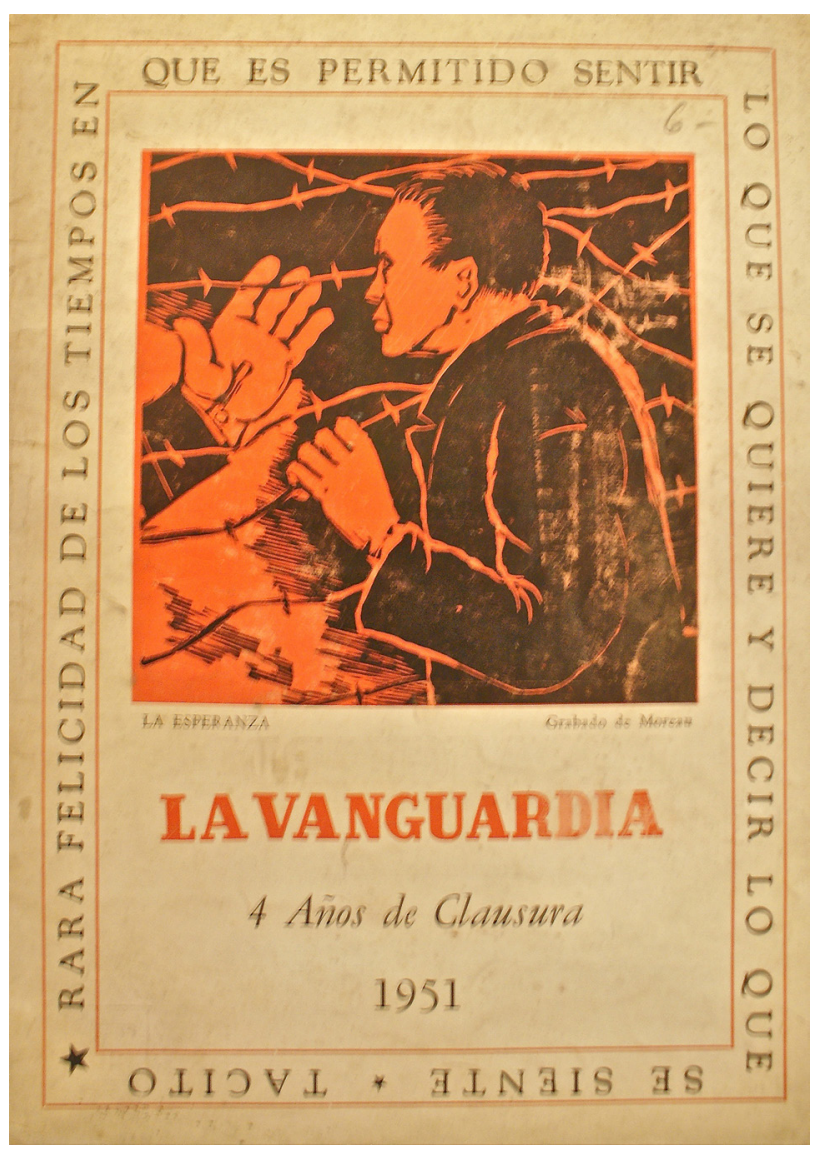

Figure 1: “4 Años de Clausura.” La Vanguardia, 1951
The Socialist Party also sanctioned other tactics, such as education and cultural diffusion, to confront Peronism and its policies. Socialists began by denouncing Peronist popular culture. Their condemnation of Peronism, like others we have seen, was made on both moral and aesthetic grounds. "It is easy to observe the general to decline of popular culture. The undue attention given to sports and the increasing vulgarity of propaganda, street exhibitions and radio transmissions have resulted in a sudden cheapening of the spirit of the nation. ${ }^{28}$ Despite a political context that they considered to be restrictive, the party indicated that staging protests within the world of representations was among their goals. "If political action is denied us, we shall try purely cultural action..."29 This quotation is less reminiscent of a Gramscian attempt to gain the upper hand and "conquer" positions of power in a cultural struggle than an attempt to "defend" cultural spaces where ideas could circulate freely. In other words, the idea of a resistance based in the world of popular culture took hold in the party's imagination. It asked "that our Centers might offer a meeting place where discussion might be free and open." ${ }^{30}$

\section{FASCIST AND PERONIST FOLKLORE}

The study of Peronism, "so that it might contribute to our battle against tyranny," was an important function of the edition of La Vanguardia that was published in exile as a supplement to the weekly El Sol published by the Uruguayan Socialist Party. The section entitled "Fascist and Peronist Folklore" contained a slew of analysis of the Peronist phenomenon. This section also made reference to the work of Italian intellectual Piero Calamandrei, who analyzed fascist folklore from the Mussolini period. Here, Argentine Socialists equated Peronism with a low-quality copy of European fascist phenomena. "It should not be forgotten that Perón was in Italy during the fascist period and even boasts of having studied in the fascist schools of Milan. His histrionics are a shoddy copy of Mussolini's histrionics." ${ }^{11}$ Once again, the Socialists pointed out that Peronism included rituals that might be considered analogous to fascist ceremonies. Socialists even drew comparisons between Peronist and fascists' tastes in uniforms and identified fascist influences in Perón's descamisados, Evita's funeral cortége, the holding of workers' beauty pageants, and the great proliferation of images of Perón and Eva. ${ }^{32}$

Another theme of the "Fascist and Peronist Folklore" section was the role of the leader as a "maker" of high culture in the role of writer and philosopher. Besides having a low opinion of the "upstart" Perón, the Socialists also detected the anxieties that underlay their perceived profanation and corruption of high culture. Indeed, Peronism's leaders embodied the sectors of the population that the old guard of Argentine cultural elite considered beyond the pale of legitimate high culture. This context lends new meanings to the Socialists' fiercest rebukes, "Perón began by declaring himself a doctor honoris causa of the University of La Plata and, in succession, of the 
country's other universities; the illiterate Eva Perón was also declared 'doctor honoris causa." "33 According to these Socialist Party diatribes, it wasn't just that the couple was arrivistes who had anointed themselves with the symbols of high culture. They epitomized a damaging cultural climate that affected the everyday life throughout the entire country that was spread by schools, parades, print publications, and even language itself. ${ }^{34}$ This last item referred to Peronism's use of popular culture, particularly signifiers from the world of the tango, through the "compulsory organization of popular singers and tango songwriters, slang terms converted into official motifs, etc." 35 The final sentence of this Socialist analysis read, "With Perón, culture becomes inferior." 36 A criticism of the "uses" of popular and, in particular, tango culture, buttressed by both morality and taste. ${ }^{37}$

As August 1955 approached and the Peronist/antiPeronist conflict grew increasingly dire, the Socialist Party began doing more than simply calling for Perón's removal from power. They also began to characterize Peronism as a historical aberration in an attempt to cordon it off from the rest of Argentine history. ${ }^{38}$ In the Socialist view, Argentines had been living "as if in an occupied country," a phrase that had its origins in the Second World War and had visual parallels to the images that had saturated the Socialist press for years. In this new political situation, the Socialists continued to promote the idea that they represented an opposition to totalitarianism. "We, then, the Argentines, are like an occupied country. More and more, the opposition takes on the form of a war for liberation." 39 This bellicose language and the exclusion of Peronism from the political spectrum show the impossibility of the Party reaching any accord with Perón's movement. When Peronism became equated with totalitarianism in the eyes of the party, it could only be defeated and forgotten as a historical abnormality.

\section{WORKERS UNDER PERONISM}

Workers were one of the main themes of Socialist graphic representations. Party iconography constructed binary representations of the world of labor. It offered, on one hand, a harsh critique of the comunidad organizada, which it blamed for a repressive and totalitarian political atmosphere and the "defrauding" of the workers. At the same time, Socialist iconography "imagined" representations that depicted their idea of how the Argentine working class should behave.

La Vanguardia generated a whole series of representations that depicted Peronism as a totalitarian government that repressed workers. In a 1947 cartoon, workers are made to pull a chariot, whose wheels are decorated with swastikas, bearing Perón and Evita. ${ }^{40}$ Another visual satire contains a clear reference to the liberties that the Socialists argued that workers lost after the Constitutional reform of 1949. The boxing glove in the image puns on the golpe with swastikas and initials of Juan Perón and Evita. ${ }^{41}$ Peronist workers were also portrayed as automatons that seemed to have lost all of their critical faculties and been made subjects of Perón. In another cartoon, a robotized worker is allowed access to Perón's constitution, pictured here as a castle. By contrast, two workers bearing signs reading "right to strike" and "unionization" are excluded. ${ }^{42}$

After the closure of La Vanguardia and the founding of Nuevas Bases, these criticisms, and their accompanying references to labor conflicts, such as the strike of the sugar industry in 1951 or the railroad strike of 1951, were steadily refined. The paper developed satirical readings of the government's reaction to this strike. In one cartoon, a character advised, "Believe me, Don Creso, coal would be fine, but for our trains, nothing works like wood." The cartoon's author plays on the popular expression "dar leña" (to give some wood), which means "to punish," and alludes to the Socialists' contention that Perón's treatment of the railroad workers was the act of an authoritarian..$^{43}$ The party also routinely protested the persecution of its own militants. The peronist government had declared the strike illegal and imprisoned their leaders. ${ }^{44}$

Along with its condemnations of government policies, the Socialist Party also produced a series of stylized images that depicted their view of how the working class should comport themselves. We find, particularly in the clandestine editions of La Vanguardia that were published in Uruguay, a sizeable repertoire of illustrations that privilege a classic twentieth century archetype of the laborer: a bare-chested masculine figure shown in movement. ${ }^{45}$ The representations convey the idea of masculinity through these figures' powerful torsos, their defiant expressions, and the presence of tools, such as hammers. ${ }^{46}$ Also the figure of a workman with a hammer, was an example was a classic piece of iconography that recalled the combative traditions of May Day celebrations. ${ }^{47}$

The selective traditions of the Socialist Party marshaled their visual resources to incorporate liberal and republican traditions that decried Peronist rites and rituals as "inauthentic." 48 The cover article of the edition of Nuevas Bases published in 1952, titled "We Propose the General Improvement of the Working Classes for through the way of Liberty," is just one example of a Socialist tract that references the "de-naturalization" of the meaning of the first of May under Peronism. ${ }^{49}$

Socialist criticisms of Peronist's policies were not limited to its so-called totalitarianism; they also made specific criticisms of the labor policies included in the Second Five-Year Plan. The Socialist Party, like the Communists, created their own repertoire of images that not only satirized capitalists, but also made Perón, whom the Socialists considered the principal beneficiary of his own plan, the target of cutting, well-aimed ridicule..$^{50}$

Socialist modes of representing workers re-created the classic aesthetic that was established in the wake of the Second International to represent those it considered "real workers." Along with these forms of representation, which conformed so closely to tradition that they might have been prescribed, there existed a spectrum of representations that depicted a range of injustices specific to Peronism, such as prison terms, strike- 
breaking, and the Congreso de la Productividad. Lastly, Socialist representations also condemned Peronism's followers as "lumpens" who were held prisoner by the government. The Party called for the re-enlistment of these "fooled" masses in their cause: "We must also reconstruct a nation that, thanks to every totalitarian technique, has been reduced to an amorphous mass, manageable only by those who are willing to pull its strings and act upon the most irrational elements of human nature." 51

\section{IMAGES CRITICAL OF PERÓN AND EVITA}

One of the principal objections to Peronism was articulated by representations that decried Perón and Evita as totalitarian leaders. La Vanguardia, which played an important role within the symbolic universe of anti-Perónism, and was one of the publications that most frequently satirized Peronism's principal figures. From the moment he assumed power, Socialists decried Perón as a military strongman who sought to emulate, in a South American fashion, the fascist leaders of Europe. The issues of La Vanguardia that went to press prior to its closure are filled with caricatures in this vein, many of which were drawn by Tristán, its cartoonist. In a cartoon of July 1949, Perón and Evita are depicted as absolute monarchs. They are shown in the act of oppressing the nation, which in this image is represented by a gaucho who is being flattened by the budget for the year $1950 .^{52}$ Of course, Perón was not the only target for the Socialists' criticisms; they also published fierce attacks on Evita. In Figure 2, a cartoon whose legend quotes Louis XIV's famous dictum: "L'etat, c'est moi" depicts her as a royal figure. This image desanctifies Evita by showing her dressed in garter belts and holding a rolling pin, well-known signifiers of, respectively, prostitutes and housewives. ${ }^{53}$ These accusations attacked the official peronist archetype of Evita that according to Marysa Navarro incarnated all the positive moral qualities of women: love, abnegation and generosity. ${ }^{54}$

After the aforementioned shuttering of La Vanguardia, later Socialist publications, most notably Nuevas Bases, began to temper their attacks on the Peróns. Pictorial criticisms of the Peronist movement veiled their criticisms of Perón and Evita, replacing them with the figure of Rosas. Therefore, in the May 1 $1^{\text {st }}, 1951$ edition of Nuevas Bases we see a caricature of that $19^{\text {th }}$ century caudillo reading that the Pronouncement of Urquiza was not being commemorated. ${ }^{55}$ Despite a decrease in the number of graphic criticisms of Perón and Eva, the Party kept up its denunciations of Peronist forms of celebration. Here we see their repudiation of a project that would have used executive power to order the minting of a golden coin with Perón's image on its obverse and the phrase "Nation, Just, Free, and Sovereign" inscribed on its other side. ${ }^{56}$ Socialists also denounced official pronunciations that praised Evita. ${ }^{57}$ The Party criticized a law passed in the province of Salta that stipulated that schools should erect

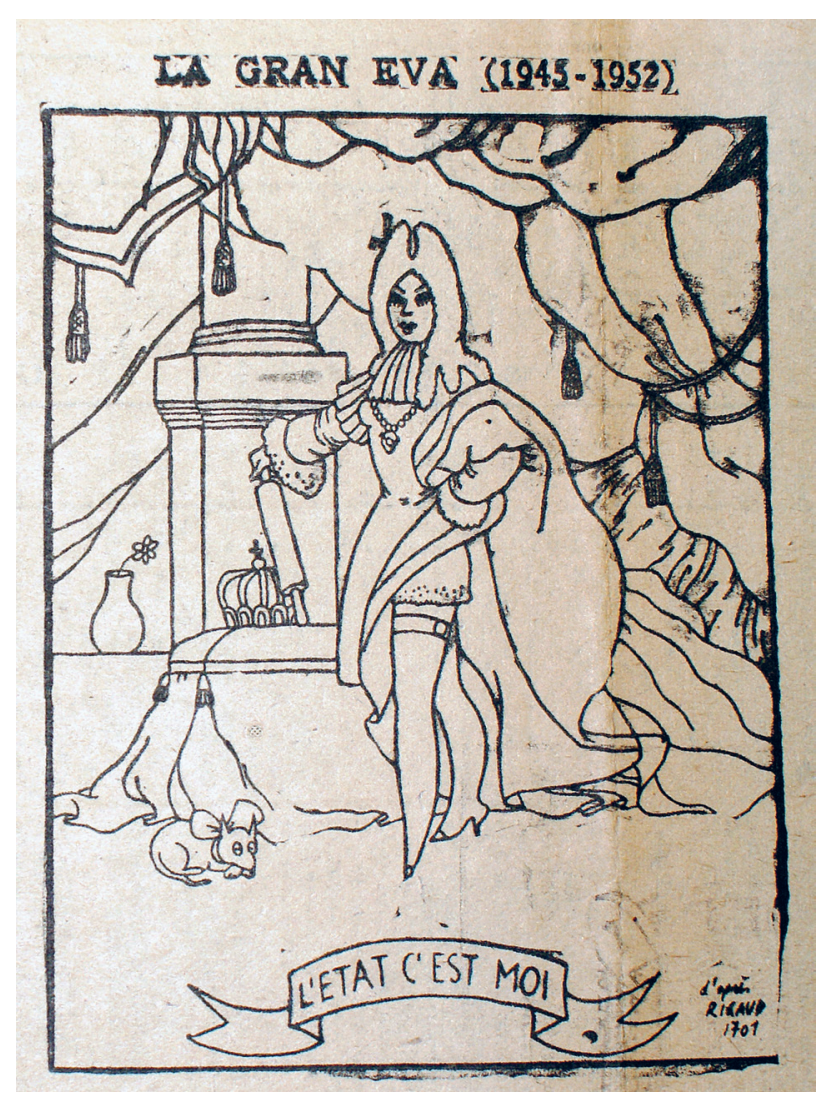

FiguRE 2: "La gran Eva (1945-1952).” La Vanguardia (circa 1952)

an altar to celebrate her life and that students' pinafores be decorated with her image..$^{58}$

While direct satires of Perón became increasingly rare in the Party's official paper, which was published in Buenos Aires, it still found ways to subvert signifiers and references to Perón. In 1953, after the assault on a Peronist demonstration, Perón's own partisans launched attacks on those they considered responsible for this incident. The Jockey Club was attacked and the Socialist Party's Casa del Pueblo was burned. ${ }^{59} 1954$ saw the zenith of the government's attempts to canonize Perón and, as a direct consequence, the worsening of the conflict between Peronism and the Catholic Church. Socialism, which held anti-clerical views, reflected this conflict. ${ }^{60}$ In a political climate where contradictions were becoming increasingly apparent, esthetic-political forms of representation became more and more extreme. Within Peronist modes of visual production, we find an increasing tendency to dehumanize the movement's adversaries. This tendency is mirrored in Socialist publications' representations of Perón, particularly in those originating from clandestine sources.

In an issue of La Vanguardia published clandestinely in Uruguay just a few days after the Navy bombed the Plaza de Mayo, an editorial declared, "While Perón remains present, there will Be no Peace in Argentina. He is the Obstacle that we Must Remove First." ${ }^{1}$ This definition of the political field and the idea of expulsing Perón 
from it makes further reference to the lack of legitimacy that Peronism itself had within the Socialist Party. Much of the opposition considered it impossible that Peronism's leader be allowed to remain part of the country's political and symbolic universe. This stance followed easily from anti-Peronism's peak: the "Revolución Libertadora." It held that:

We cannot coexist with the dictator. It is necessary to eliminate him in order to establish peace... Of course, when we speak of eliminating Perón, we refer to the elimination of his power. If he wishes to live, let him do so. And he will surely have to do so following the same path Rosas took after his defeat: going to die in England after having reviled her for the entirety of his political career. $^{62}$

It is interesting that the writer establishes a genealogical link between Rosas and Perón by emphasizing the necessity of sending the latter into exile. ${ }^{63}$

In the months prior to the fall of Peronism, the ways in which Perón was represented began to take on a more extreme character. An article entitled, "What Is Happening to Mr. President?" published after Perón made his famous declaration that "for every one of ours, five of theirs will fall," the Socialist Party attempted to make a direct connection between the head of state's words and the speeches of Rosas, Mussolini, and Hitler and suggested that the episode of violence that the country was experiencing should be interpreted as a symptom of decadence. ${ }^{64}$ Taking a perhaps excessively psychologized view of these events, they argued that the country's crisis was condensed in the figure of Perón, "a dangerous neurotic who has made violence his creed and declared that the murder of his enemies is a civic virtue." ${ }^{65}$ Taking their criticism to extreme, they drew on the rhetorical structures of the post Second World War, "In his speech, the President urged the crime of genocide, a new penal category created by the mass crimes of Nazism." The illustration that accompanied the article depicted the full spectrum of violent acts that the Socialists held Perón's government accountable for. ${ }^{66}$ In a sidebar titled "Perón, Preacher of Crime," the publication transcribed a series of speeches by Perón in an attempt to illustrate the seriousness of the latest political violence and once again compared Perón to Rosas and Hitler. ${ }^{67}$ Lastly, the publication posited that Peronism itself was a crime, showing Perón's silhouette traced in blood (see Figure 3 ). ${ }^{68}$

After the events of September 1955 the party described Perón's flight from Argentina using bellicose language that complemented their graphic representations of him. The Socialists sought to establish a genealogical link between these events and the Battle of Caseros, at which the forces of Juan José de Urquiza defeated Juan Manuel de Rosas in 1852. ${ }^{69}$ After Peronism's defeat, Socialist leaders such as Américo Ghioldi returned from Uruguay. Thus various party members played important civilian roles in the so-called "Revolución Libertadora" that began in 1955 .

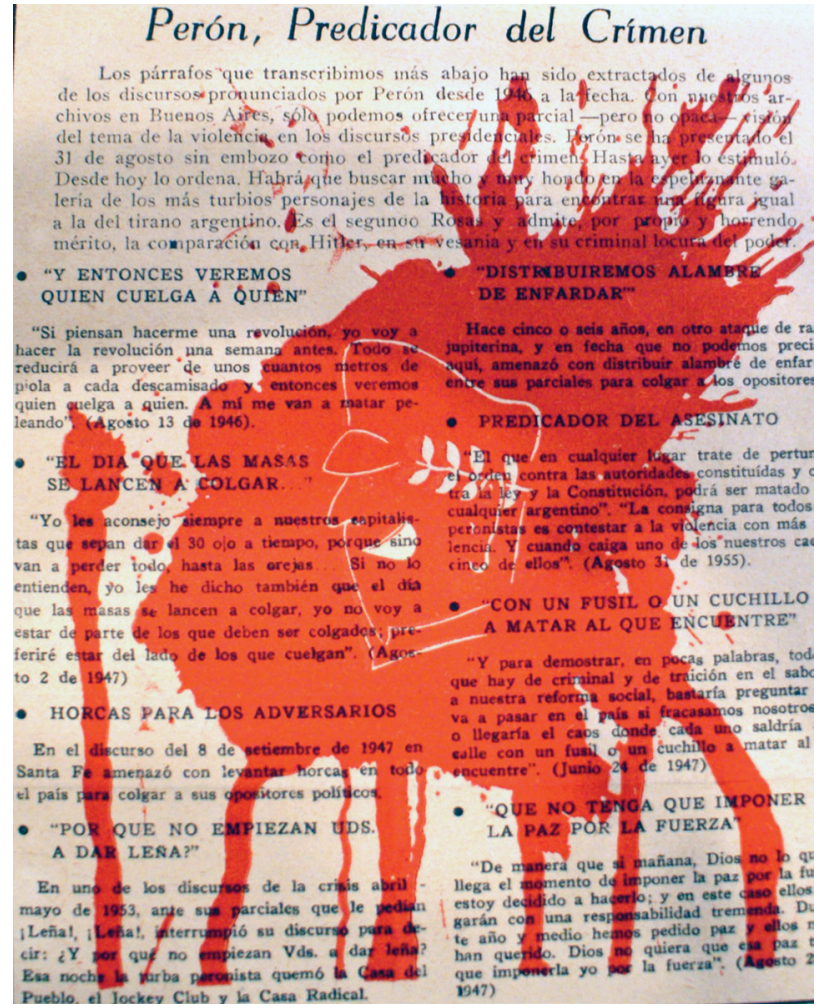

Figure 3: "Perón, Predicador del Crimen", 8 September 1955

\section{CONCLUSIONS}

Studying the ways in which the Socialist party stigmatized Peronism allows us to discern how the language of the Cold War period was used to describe the dynamics of Argentina's political and cultural conflicts. This article sought to go beyond the traditional perspectives of Cold War historiography, whose focus is on diplomatic and military history and the bulk of whose analysis is devoted to dissecting the United States' attempts to establish hegemony over Latin America or to describing the phenomenon of justicialismo's "third position." This article, on the other hand, sought to use cultural analysis to explore Latin America's own agency in its adoption of language pertaining to the early Cold War period. This was how Peronism was stigmatized in socialist publications like Nuevas Bases and La Vanguardia. Socialists crafted a stylized, and sometimes exaggerated, discourse in which imagery belonging to fascism and, to a lesser extent, Stalinism after the rise of the Iron Curtain, was combined with the local figure of nineteenth century governor Juan Manuel de Rosas. Juan Perón and Evita were declared to be the leaders of a totalitarian state and Argentine workers to be prisoners of a phenomenon that they considered "aberrant" in the larger view of Argentine history. Faced with this situation, socialists rallied the Resistencia and sought to recover a liberal ideology.

As the cultural and political project of the peronist organized community moved forward during the early 1950s, social conflicts began to crop up. Different work- 
ers' strikes were triggered as of 1950, all surrounded by many images that went against Peronism. Socialists participated both in the 1950 sugar strike and in the 1951 railroad struggle. This last strike was declared illegal and most of the union leaders were imprisoned. Within this conflict, different Socialist graphic publications constantly denounced the imprisonment of their leaders and what they considered to be the arbitrariness and totalitarianism of the Peronist government.

The level of conflict between the opposition and Peronism reached levels of extreme violence that went beyond the symbolic sphere when, in 1953, the Socialist Casa del Pueblo was set into fire by followers of Perón. Within this setting of mutual political exclusions, both the government and the Socialists made extremes ways of representation that tried to "de-humanize" each other. In 1954, Perón became canonized as a leader. Socialists, hence, increased images that tried to compare the president of Argentina with Rosas, Hitler, or Mussolini. In this way, the Socialist party visual production made emphasis on the characterization of Perón as a local representation of totalitarianism. The characterization of Perón's government as "totalitarian" would spread out the narrow boundaries of the actual party and would also be present in the following administration. The so-called "Revolución Libertadora" that overtrew Perón in 1955 did not hesitate to stigmatize the previous Peronist experience as a domestic example of "totalitarianism." The language that was used to describe the rifts occasioned by the Cold War and to stigmatize Peronism, which would be outlawed by Argentina's de facto government, was deployed again during the "Revolución Libertadora."

\section{ACKNOWLEDGMENTS}

I would like to thanks to Marysa Navarro, Brooke Larson and Eric Zolov for their comments.

\section{NOTES}

1. For a classic definition of totalitarianism see Arendt (1951).

2. We also follow the analyses of art historian Michel Baxendall who studied Italian Renaissance's paintings. Baxendall claims that painting is "the deposit of a social relationship." Baxandall (1988:1).

3. For the Socialist Party, see Camarero and Herrera (2005).

4. For an interesting contribution on Peronism and culture, see Karush and Chamosa (2010). Also Karush, (2012).

5. The leading socialist figure in those years was Juan B. Justo, who, along with other pioneering activities, completed the first translation of Marx's Das Kapital into Spanish.

6. Cited in James (1988a: 441-461).

7. Juan Manuel de Rosas was governor of the province of Buenos Aires twice, from 1829 to 1832 and again from 1835 to 1852 . During his second stint as governor, he held absolute power and was also considered the restorer of the law. His figure and legacy is the source for heated political and historical debate within Argentina.

8. It is important to note the role of liberal ideology in the Socialists' platform and this ideology's relationship to the Socialist Party's evolutionist and progressivist views on the political changes that were thought necessary in Argentina. For example, La Lucha, in an editorial for September $2^{\text {nd }}, 1949$, titled "Ariete y yunque," we find the following statement: "Since those who are brought up and educated in a social and democratic school, one that has as its first priority the mental and moral growth and preparation of its activists and the foundation of a movement of vast historical proportions, whose aims are the consolidation of liberty and increasing the dignity of the citizen and worker...LA LUCHA will support and second the everyday action of Argentine Socialism in defense of ideas and ideals that have substantial and vital influence on the evolutionary and progressive process of the entire civilized community. Democracy, which we practice and think of as a duty and a mandate, is not and never shall be for us a mere word, used only for its effect on the suggestible masses, nor a recruitment banner with which to promote demagogic and providential plans." This editorial ended in the upbeat tone characteristic of nineteenth-century idealists, "encouraged by the certainty and sure of the triumph of truth and reason." La Lucha, $[L L]$ "Ariete y yunque", 2 September 1949, 1.

9. $[L L]$, "Se inició proceso al director de 'La Lucha'," 7 March 1950,1 . This article mentions the detention and trial of Juan Antonio Solari.

10. Herrera (2005: 343-366). Our analysis of the Socialists' characterization of Peronism includes their comparison of Rosas and Perón, which is not found in Herrera's article.

11. For additional caricatures of Rosas, see the issue of Nuevas Bases for July 1954, in which one illustration shows the re-internment of Rosas' remains in Buenos Aires.

12. $[N B]$ “Cultura, la enseñanza y el periodismo bajo Rosas", 30 September 1950. "The restorer of law" was another way to refer to Rosas.

13. Swampa describes how that concept of barbarity, in the tradition of Sarmiento, was used to criticize various Argentine political trends that existed prior to Peronism, such as Hipolito Irigoyen's Radical government of 1916. Swampa (2006: 320).

14. Both the reference to the execution of Camila O'Gorman and the phrase "one savage fewer" are meant to remind the reader of the "salvajes unitarios" of liberalism's own symbolic traditions. The unitarios were the faction that opposed the so-called federales and clashed with them during the opening decades of the nineteenth century.

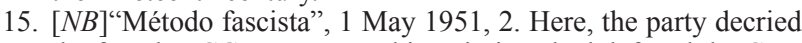
the fact that CGT posters and inscriptions had defaced the Casa del Pueblo. On page 7 of this same issue we find a cartoon that suggests that fascism and dictatorship treat imprisoned workers similarly.

16. $[N B]$ "De los presentes días de luto", 30 June 1951, 1.

17. $[N B]$ "Esto es Justicialismo!", 30 June 1951.

18. $[N B]$ "El 22 de Agosto fue el Éxito del Estado Totalitario. Por Primera Vez en el País un Presidente se Declara Sucesor de sí Mismo", 27 August 1951, 8-9.

19. Ibid. Another article that critized the Soviet Union trough the Cold War's language is $[N B]$ "Stalin. Un pueblo Sometido y una Burocracia Todopoderosa", 25 March 1953.

20. $[L V]$ "En el cuarto año de la ignominia", 1951.

21. Ghioldi lecturer at Columbia University. Américo Ghioldi to Nicolas Repetto, letter, 2 January 1955, Fondo Nicolas Repetto, (CEDINCI), Buenos Aires.

22. “Hasta Cuando?” July, 1951

23. [LV] "Peronedro" July, 1954.

24. [LV] "4 Años de Clausura", 1951.

25. The Primera Junta was the first government established by the revolutionary congresses of 1810 . For more information, see Halperín Donghi (1997).

26. [LV] "En el cuarto año de la ignominia", 1951. Issue published clandestinely in Uruguay.

27. [LV]"Canto a la Resistencia", 1951.

28. $[N B]$ "Actividad Socialista Se intensificará la Labor Cultural de Nuestro Partido", April 1952, 3.

29. Ibid.

30. Ibid.

31. [LV]"Folklore Fascista y Peronista", 23 June 1954, 1. Issue published clandestinely in Uruguay. For more on Mussolini as leader, see Antliff (2007: 55). 
32. In a letter from Américo Ghioldi to Nicolas Repetto he also claims this kind of characterization of peronism. Américo Ghioldi to Nicolas Repetto, letter, 19 January 1953, Fondo Nicolás Repetto, Centro de Documentación e Investigación de Izquierda en Argentina (CEDINCI).

33. $[L V]$ "Folklore Fascista y Peronista III", 7 July 1954. 1. Issue published clandestinely in Uruguay.

34. [LV]"Filologia Piriforme." La Vanguardia, July 14, 1954, 1. Issue published clandestinely in Uruguay. This article mentions that Perón sought to hold a philology conference in Buenos Aires. It went on to criticize this idea and mention the earlier expulsion of professors. Lastly, the article gives the impression that the Peronists are working in a field in which they are considered strangers and therefore lack legitimacy. "A Peronist parliament that sports intellectual espadrilles is one of the most active organizers of the proposed assembly on piriforme philology."

35. [LV] "Folklore Fascista y Peronista III", 7 July 1954, 1. Issue published clandestinely in Uruguay.

36. Ibid

37. James describes how Perón's speeches were composed entirely in a style that echoed various forms of popular sentiment. His speeches and ceremonies performed in the Plaza de Mayo, therefore, also borrowed elements from tango. One example of his use of the tango's dialect can be found in a speech delivered on October $17^{\text {th }}, 1945$. James writes, "Towards the end of that speech, Perón evoked the image of his mother, "mi vieja." See James (1988b: 22-23).

38. [ $[\mathrm{V}]$ "La dictadura vive su momento existencial." 24 August 1955,1 . The article continued, "Some would believe that the creator of all this chaos has been the architect of a revolution, a revolution, in any case, that has disrupted values, subverted concepts, profaned words, and prostituted institutions. No deepseated transformation can be assessed in Peronism's favor, neither social, nor economic, nor political." The idea that fascism was a true "parenthesis" within Italian history can be attributed to liberal philosopher Benedetto Croce. For more on fascism, see Paxton (2004).

39. [LV] “Como en país ocupado", 8 September 1955, 1. Issue published clandestinely in Uruguay.

40. [LV]"Ilusión y Realidad",16 December 1947.

41. $[L L]$ "La caja de las sorpresas",1 November 1949.

42. "Engaño Tragico" La Vanguardia.

43. [NB] March 1951, 1. For the context of the railroad strike of 1951, see Doyon (2006: 312)

44. "1951 año del sindicalismo obreros presos en la cárcel de Villa Devoto," Nuevas Bases, May 15, 1951, 50. In the light of Herrera's article, it is important to note that in "Juan del Riel," the Socialists created an archetypical figure of the militant working class who had been imprisoned thanks to the labor strike. See also Herrera, El Partido Socialista en Argentina, 356.

45. $L V, 1951$

46. "En el cuarto año de la Ignominia." La Vanguardia, 1951. For the construction of the image of the worker, see Bonnell (1997: 21-46).

47. $N B 1$ May 1952

48. [NB] "1889-1. de Mayo-1952 por un pueblo Argentino libre y grande en un mundo de paz, fraternidad y justicia" 1 May 1952,1 .

49. Ibid.

50. [LV]‘Acuerdo' Entre Capital y Trabajo”, 1955.

51. [LV]"El Gran Pueblo Argentino Terminó con el Peronato," 22 September 1955, 1. Issue published clandestinely in Uruguay.

52. [ $L V]$ "Opinión Oficial", 19 July 1949. For another example of an illustration showing the ruling couple oppressing the working class, see $[L V] 16$ December 1947.

53. For the Socialist Party's stance on Eva Perón, see the article composed after her death by Nicolás Repetto. It is less an obituary than a criticism of Peronism's failings. It discusses political prisoners, exiles, and the government's failure to keep public order, see $[N B]$ "Eva Perón" 5 August 1952, 1.

54. For more details on this definitions see Navarro, Evita, 335.
55. See $[N B] 1$ May 1951, 1. In the cartoon, Rosas can be seen reading the caption "Gral. Urquiza's pronouncement will not be officially celebrated," and exclaiming, "I expected no less!" Urquiza's pronouncement is considered to be the beginning of Juan Manuel de Rosas's fall from power in 1852, an event celebrated within the liberal tradition as a milestone in the construction of a modern Argentine nation.

56. $[N B]$ "Y ahora el Perón de oro", 27 August 1951, 2.

57. In much opposition discourse, the figure of Eva Perón represented the most extreme elements of Peronism in terms of demagogy, the manipulation of the poorer classes, and the arbitrary use of power. The most extreme examples of antiEvita sentiment could be found on the walls of Buenas Aires during her illness, which featured graffiti reading "Long live cancer!"

58. $[N B]$ "Culto dirigido y obligatorio", January 1953.

59. It is important to note that Perón himself had attempted to split the Socialist constituency using his so-called Partido Socialista de la Revolución Nacional, led by ex-Socialist Enrique Dickmann.

60. [NB]“¿Qué Pasa?”, December 1954, 1.

61. [LV]"Mientras Perón no Desaparezca no Habrá Paz en Argentina. Él es el Obstáculo que Debemos Remover en Primer Lugar", 29 Jun 1955, 1. Issue published clandestinely in Uruguay. 62. Ibid.

63. Perón spent his exile in Paraguay, Venezuela, Panama, and Spain and did not return to Argentina until 1972.

64. In an article titled "Canto de amor a Alemania nazi" (Love Song to Nazi Germany), the Socialists used analyses of Perón's speeches to conclude that he sympathed with the Nazi regime, [LV] 4 May 1954, 1. Issue published clandestinely in Uruguay.

65. [LV]“¿Qué le pasa al Sr. Presidente?”, 29 June 1955, 1. Issue published clandestinely in Uruguay.

66. [LV]"Argentina Esta a Merced de un Neurótico Peligroso que ha Hecho de la Violencia su Evangelio y del Crimen Virtud Cívica",8 September 1955.

67. Ibid.

68. [LV]"Perón, Predicador del Crimen", 8 September 1955.

69. [LV]"Rendición incondicional", 22 September 1955, 1. In this article, the Socialists charge that the head of state wished to be adored like "Mohammed, Christ, and Napoleon." Issue published clandestinely in Uruguay.

\section{REFERENCES}

Antliff, Mark (2007) Avant-Garde Fascism: The Mobilization of Myth, Art, and Culture in France, 1909-1939. Duke University Press, Durham.

Arendt, Hannah (1951) The Origins of Totalitarianism. New York.

Baxandall, Michael (1988) Painting \& Experience in fifteen-century Italy. Oxford University Press, London.

Bonnell, Victoria E. (1997) Iconography of Power Soviet Political Posters under Lenin and Stalin. University of California Press, Berkeley.

Burke, Peter (2001) Eyewitnessing: The Uses of Images as Historical Evidence. Cornell University Press, Ithaca.

Calandra, Benedetta and Marina Franco (2012) La guerra fría cultural en América Latina. Desafios y límites para una nueva mirada de las relaciones interamericanas. Biblos, Buenos Aires.

Camarero Hernán and Carlos Miguel Herrera, (eds.), (2005) El Partido Socialista en Argentina: Sociedad, politica e ideas a través de un siglo. Editorial Prometeo, Buenos Aires.

Capelato, María Helena Rolim, (1998) Multidoes em cena: propaganda politica no varguismo e no peronismo. Papirus, San Pablo.

Doyon, Louise M. (2006) Perón y los trabajadores: Los orígenes del sindicalismo peronista, 1943-1955. Siglo Veintiuno, Buenos Aires.

Elena, Eduardo (2011) Dignifying Argentina: Peronism, Citizenship, and Mass Consumption. University of Pittsburg Press, Pittsburg. 
Gené, Marcela (2005) Un mundo feliz: imágenes de los trabajadores en el primer peronismo, 1946-1955. Fondo de Cultura económica, Buenos Aires.

Halperín Donghi, Tulio (1997) Revolución y guerra: Formación de una elite dirigente en la Argentina criolla. Siglo Veintiuno, Buenos Aires.

Harmer, Tanya. (2011) Allende's Chile and the Inter-American Cold War. University of North Carolina Press, Chapel Hill.

Hunt, Lynn (1984) Politics, Culture and Class in the French Revolution. University of California Press, Berkeley.

James, Daniel (1988a) "October $17^{\text {th }}$ and $18^{\text {th }}$, 1945: Mass Protest Peronism and the Argentine Working Class". Journal of Social History, 21 (3): 441-461.

James, Daniel (1988b) Resistance and Integration: Peronism and the Argentine Working Class 1946-1976. Cambridge University Press, Cambridge.
Karush, Mattew B. and Oscar Chamosa, (eds.) (2010) The New Cultural History of Peronism: Power and Identity in Mid-Twentieth Century Argentina. Duke University Press, Durham.

Karush, Mattew (2012) Culture of Class: Radio and Cinema in the Making of a Divided Argentina, 1920-1946. Duke University Press, Durham.

Morgenfeld, Leandro (2011), Vecinos en Conflicto, Argentina y Estados Unidos en las Conferencias Panamericanas (1880-1955). Peña Lillo, Ediciones Continente, Buenos Aires.

Navarro, Marysa (2011) Evita. Edhasa, Buenos Aires.

Paxton, Robert (2004) Anatomy of Fascism. Alfred A. Knopf, New York.

Plotkin, Mariano Ben (2007) Mañana es San Perón: Propaganda, rituales politicos y educación en el régimen peronista (1946-1955). Editorial de la Universidad Nacional de Tres de Febrero, Buenos Aires.

Svampa, Maristella (2006) El Dilema Argentino Civilización o Barbarie. Taurus, Buenos Aires. 